\title{
DNA-BASED DETECTION OF WESTERN GALL RUST
}

\author{
T.D. RAMSFIELD ${ }^{1}$ and D.R. VOGLER ${ }^{2}$ \\ ${ }^{1}$ Forest Research, Private Bag 3020, Rotorua, New Zealand \\ ${ }^{2}$ Institute of Forest Genetics, USDA Forest Service, Pacific Southwest Research \\ Station, 1100 West Chiles Road, Davis, CA 95616-6138, USA
}

Corresponding author: Tod.Ramsfield@forestresearch.co.nz

\begin{abstract}
The internal transcribed spacer (ITS) region of the nuclear ribosomal DNA of the western gall rust fungus (Peridermium harknessii) was amplified using the basidiomycete-specific PCR primers ITS1-F and ITS4-B. The PCR product was then sequenced and aligned with other pine stem rust ITS sequences and a conserved region within $P$. harknessii was targeted with the novel PCR primer Phar1. Our PCR protocol was able to differentiate $P$. harknessii from Cronartium comandrae and $C$. coleosporioides and detected $P$. harknessii within infected host tissue. However, $P$. harknessii was not distinguishable from $C$. quercuum $\mathrm{f}$. sp. fusiforme. The method provides a rapid and sensitive detection protocol for $P$. harknessii and C. quercuum f.sp. fusiforme within infected host tissue.

Keywords: Western gall rust, Peridermium (Endocronartium) harknessii, DNA detection.
\end{abstract}

\section{INTRODUCTION}

Western gall rust (caused by Peridermium harknessii J.P. Moore syn. Endocronartium harknessii (J.P. Moore) Y. Hiratsuka), is an autoecious rust disease of hard pines (Hiratsuka 1969), including Pinus radiata D. Don (Parmeter \& Newhook 1967). Peridermium harknessii is a close relative of the rust genus Cronartium, members of which cause disease on many species of Pinus throughout the world. It is hypothesised that $P$. harknessii is an autoecious derivative of its closest relative, Cronartium quercuum f. sp. banksianae, or a recent common ancestor (Vogler \& Bruns 1998). Aeciospores produced on galls in spring and early summer directly infect young elongating pine shoots, causing formation of galls on branches or the main stem (van der Kamp 1989). These galls begin to sporulate within one-to-two years of infection (Old 1981). Colonisation of the main stem can lead to breakage at the infection point (Peterson 1960) or formation of characteristic hip cankers (Old 1981). In North America, western gall rust ranges from the Yukon to Baja California, and from the Pacific to the Atlantic Coasts (van der Kamp 1989). Western gall rust poses a potential threat to P. radiata in the Southern Hemisphere, where it is grown extensively in plantations (Parmeter \& Newhook 1967; Old 1981; Old et al. 1986; van der Kamp 1989).

Rapid detection and implementation of an incursion response is necessary to prevent establishment of a disease (Hosking et al. 1999). Therefore, a method of detection that does not rely upon spore production would be advantageous because infected material could be identified and destroyed quickly, and prior to sporulation and potential spread of the fungus. Although $P$. harknessii has been grown in axenic culture, fungal growth from infected tissue is slow and the fungus does not always emerge from infected host material (Allen et al. 1988). Additionally, Lundquist et al. (1994) found that the fungus emerged only from galls that were collected immediately prior to aeciospore production. These limitations, and the advent of polymerase chain reaction (PCR) based molecular diagnostic techniques, have spurred the development of a species-specific DNA marker for western gall rust. A successful molecular detection technique must detect at the species, not the individual level, and it must not amplify host DNA. 
The objective of this study was to develop a rapid PCR-based protocol that could detect $P$. harknessii mycelium within infected host tissue prior to sporulation. This rapid diagnostic test could be used by inspecting agencies in countries where gall rust is not known to occur, in the event of discovery of pine tissue with suspicious gall formation.

\section{Collection of fungal material}

\section{MATERIALS AND METHODS}

Western gall rust-infected lodgepole pine (Pinus contorta Dougl. ex Loud. var. latifolia Engelm.), ponderosa pine (P. ponderosa P. Laws. ex C. Laws) and shore pine (P. contorta Dougl. ex Loud. var. contorta) branches, as well as samples of Cronartium coleosporioides Arth. and C. comandrae Peck, were collected from locations throughout British Columbia in May and June 2002. The peridial layer was either intact or recently ruptured and aeciospores were present. Galls with evidence of hyperparasitism were not collected. In the laboratory, aeciospores were removed by rupturing the peridial layer, if required, and tapping the spores into sterilised weigh boats. Spores were purified from contaminating wood and debris by sieving through nylon mesh with a $1 \mathrm{~mm}$ pore size, followed by further sieving through $105 \mu \mathrm{m}$ mesh (Small Parts Inc., Miami Lakes, FL). Purified aeciospores were stored at $-80^{\circ} \mathrm{C}$ until DNA was extracted.

\section{Extraction of DNA}

DNA extraction from aeciospores of P. harknessii, C. coleosporioides and C. comandrae followed the minipestle (Pellet Pestles ${ }^{\circledR}$ from Kontes-Kimble, Vineland, $\mathrm{NJ}$ )/diatomaceous earth method of Zambino (2002) without modification. Total DNA was isolated from galled $P$. contorta var. latifolia and $P$. contorta var. contorta branches, and fresh leaders of $P$. contorta var. latifolia, $P$. contorta var. contorta and $P$. ponderosa to provide samples that included host and pathogen DNA, and pure host DNA, respectively. A $2 x$ CTAB extraction protocol based on the method of Vogler \& Bruns (1998) was used with the following modification: initially, the outer bark was removed using a sterile scalpel, and the inner tissues were cubed and then frozen and ground to a fine powder in liquid nitrogen. DNA of Cronartium quercuum (Berk.) Miyabe ex Shirai f. sp. fusiforme (Cumm.) Burds. et Snow and P. radiata was provided.

\section{ITS PCR amplification and $P$. harknessii primer design}

The universal basidiomycete PCR primers ITS1-F and ITS4-B were used to amplify the internal transcribed spacer regions and the 5.8s rRNA gene of the ribosomal DNA repeat from $P$. harknessii, C. comandrae and $C$. coleosporioides following the method of Gardes \& Bruns (1993). The PCR products were purified using StrataPrep® PCR purification columns (Stratagene, La Jolla, CA), ligated into the pPCR-Script Amp (Stratagene, La Jolla, CA) vector, inserted into XL1-Blue MRF' kan electroporation competent cells (Stratagene, La Jolla, CA) and sequenced using M-13 forward and reverse primers on an ABI 3100 automated sequencer. The ITS sequences of three isolates of $P$. harknessii, each from a different host, and C. comandrae and C. coleosporioides, as well as ITS sequences from GenBank (Table 1), were aligned using Gene Runner (Hastings Software).

A region that was conserved within $P$. harknessii, yet was variable from other rust species (Table 2) was used to design the P. harknessii specific PCR primer Phar1. An Eppendorf MasterCycler gradient was utilised to empirically determine that the optimum annealing temperature of Phar 1 was $55^{\circ} \mathrm{C}$. The amplification conditions were therefore $10 \mu \mathrm{M}$ Phar1, $10 \mu \mathrm{M}$ ITS4-B, $200 \mathrm{~nm}$ dNTP, 0.5 units Taq DNA polymerase (Roche New Zealand Ltd.), the supplied Roche buffer with a final $\mathrm{MgCl}_{2}$ concentration of $1.5 \mathrm{mM}$, and $1 \mathrm{ng}$ target DNA. Thermal cycling conditions were as follows: $94^{\circ} \mathrm{C}$ for 2 min, followed by 30 cycles of $94^{\circ} \mathrm{C}$ for $30 \mathrm{~s}, 55^{\circ} \mathrm{C}$ for $30 \mathrm{~s}$ and $72^{\circ} \mathrm{C}$ for $1 \mathrm{~min}$ with a final extension at $72^{\circ} \mathrm{C}$ for $7 \mathrm{~min}$.

\section{Sensitivity determination}

The sensitivity of the method was determined by adding decreasing amounts of $P$. harknessii target DNA to PCR reactions that contained $10 \mathrm{ng}$ of $P$. radiata DNA to determine the limit of detection. A total of $10 \mathrm{ng}, 5 \mathrm{ng}, 1 \mathrm{ng}, 0.5 \mathrm{ng}, 0.1 \mathrm{ng}, 0.05 \mathrm{ng}, 0.01$ 
ng, $0.001 \mathrm{ng}$ and $0.0001 \mathrm{ng}$ of $P$. harknessii DNA was added to PCR reactions, prepared as described, resulting in ratios of 1:1 to 100,000:1 (host DNA:pathogen DNA).

\section{TABLE 1: Rust ITS sequences downloaded from GenBank.}

\begin{tabular}{ll}
\hline Rust species & GenBank accession number \\
\hline Chrysomyxa arctostaphyli & $\mathrm{L} 76488$ \\
Cronartium appalachianum & $\mathrm{L} 76484$ \\
Cronartium arizonicum & $\mathrm{L} 76504$ \\
Cronartium comptoniae & $\mathrm{L} 76487$ \\
Cronartium conigenum & $\mathrm{L} 76486$ \\
Cronartium flaccidum & $\mathrm{X} 83911$ \\
Cronartium quercuum & $\mathrm{L} 76495$ \\
Cronartium occidentale & $\mathrm{L} 76507$ \\
Cronartium ribicola & $\mathrm{L} 76499$ \\
Cronartium strobilinum & $\mathrm{L} 76482$ \\
Peridermium bethelii & $\mathrm{L} 76479$ \\
Pucciniastrum goeppertianum & $\mathrm{L} 76509$ \\
\hline
\end{tabular}

TABLE 2: Sequence alignment of PCR primer Phar1 and rust DNAs.

\begin{tabular}{|c|c|c|}
\hline$\underline{\text { Rust species }}$ & ec & ace \\
\hline har1 primer se & 5 & GT T AT T T C \\
\hline & 5 & ---3 \\
\hline & 5 & $------\mathrm{A}------\mathrm{T}----\mathrm{G}----3$ \\
\hline & 5 & $-----\mathrm{T}----\mathrm{G}----3^{\prime}$ \\
\hline & 5 & $------\mathrm{T}----\mathrm{G}----3^{\prime}$ \\
\hline achianum & 5 & $-\mathrm{C}--\mathrm{T}-\mathrm{A}------\mathrm{T}----\mathrm{G}----3^{\prime}$ \\
\hline ioides & 5 & $-\mathrm{C}--\mathrm{T}-\mathrm{A}-----\mathrm{T}----\mathrm{G}----3$, \\
\hline & 5 & $-\mathrm{C}--\mathrm{T}-\mathrm{A}------\mathrm{T}----\mathrm{G}----3^{\prime}$ \\
\hline & 5 & $-\mathrm{C}--\mathrm{T}-\mathrm{A}------\mathrm{T}----\mathrm{G}----3^{\prime}$ \\
\hline$m$ & 5 , & $-\mathrm{C}--\mathrm{T}-\mathrm{A}------\mathrm{T}----\mathrm{G}----3$, \\
\hline tale & 5 & $-\mathrm{C}--\mathrm{T}-\mathrm{A}------\mathrm{T}----\mathrm{G}----3$, \\
\hline$C$ & 5 & $-\mathrm{C}--\mathrm{T}-\mathrm{A}------\mathrm{T}----\mathrm{G}----3$, \\
\hline im bethelii & 5 & $-\mathrm{C}--\mathrm{T}-\mathrm{A}------\mathrm{T}----\mathrm{G}----3$, \\
\hline ctostaphy & 5 ' & $-\mathrm{C}-\mathrm{CAT}-\mathrm{A}-\mathrm{GT}$ GAA $-\mathrm{T}--\mathrm{TAA}-\mathrm{T} 3^{\prime}$ \\
\hline ucciniastrum goeppertianum & 5 & $-\mathrm{C}-\mathrm{CAT}-\mathrm{A}-\mathrm{GAGCT}-\mathrm{TA}-\mathrm{TC}---3^{\prime}$ \\
\hline
\end{tabular}

\section{RESULTS}

Amplification of DNA with ITS1-F and ITS4-B from P. harknessii, C. comandrae, C. coleosporioides and $C$. quercuum $\mathrm{f}$. sp. fusiforme, as well as from P. harknessii and C. coleosporioides-infected $P$. contorta var. latifolia, resulted in a band of approximately 1000 base pairs (bp) in all cases (Fig. 1). The 1000 bp band was not amplified from uninfected $P$. contorta var. latifolia or $P$. radiata DNA (Fig. 1). When the primer Phar1 was used in conjunction with ITS4-B, a 700 bp band was amplified from P. harknessii, $P$. harknessii-infected $P$. contorta var. latifolia and $C$. quercuum f. sp. fusiforme. DNA from Cronartium comandrae, $C$. coleosporioides, $P$. contorta var. latifolia and $P$. radiata was not amplified by Phar1 and ITS4-B (Fig. 2). All isolates of P. harknessii that were collected in this study were amplified by Phar1 and ITS4-B, regardless of host origin. 


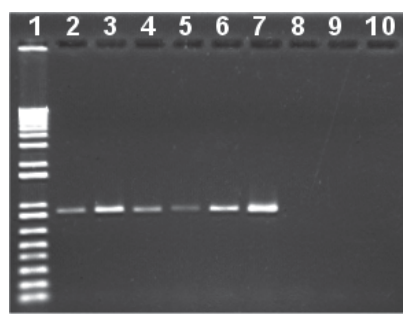

FIGURE 1: Amplification products generated by ITS1-F and ITS4-B. 1.1 kb+ ladder, 2. P. harknessii, 3. C. comandrae, 4. C. coleosporioides, 5. C. quercuum f. sp. fusiforme, 6. P. harknessii-infected $P$. contorta var. latifolia, 7. C. coleosporioides infected $P$. contorta var. latifolia, 8. $P$. contorta var. latifolia, 9. $P$. radiata, 10 . Water negative control.

Although gradient PCR indicated that $P$. harknessii DNA was amplified with annealing temperatures up to $63.5^{\circ} \mathrm{C}$ and $C$. quercuum f.sp. fusiforme was only amplified at annealing temperatures up to $60.8^{\circ} \mathrm{C}$, the diagnostic band was too faint at $63.5^{\circ} \mathrm{C}$ to be considered as a reliable marker. Therefore, the annealing temperature was lowered to $55^{\circ} \mathrm{C}$, which resulted in strong amplification of both rust species. When the sensitivity of detection was determined by adding decreasing amounts of pathogen DNA to PCR reactions that contained host DNA, it was found that the diagnostic band was amplified when the amount of pathogen DNA was between $10 \mathrm{ng}$ and $0.05 \mathrm{ng}$.

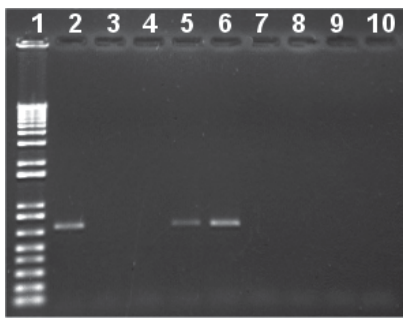

FIGURE 2: Amplification products generated by Phar1 and ITS4-B. 1. 1 kb+ ladder, 2. P. harknessii, 3. C. comandrae, 4. C. coleosporioides, 5. C. quercuum f. sp. fusiforme, 6. $P$. harknessii-infected $P$. contorta var. latifolia, 7. C. coleosporioides-infected $P$. contorta var. latifolia, 8. . contorta var. latifolia, 9. P. radiata, 10. Water negative control.

\section{DISCUSSION}

Western gall rust, caused by Peridermium harknessii, is a serious threat to $P$. radiata plantations in New Zealand due to the amenable climate and the fact that no alternate host is required for completion of the rust life cycle (Parmeter \& Newhook 1967; Old 1981; Old et al. 1986; van der Kamp 1989). Western gall rust is not present in New Zealand; therefore, a sensitive detection technique is needed to respond to an inadvertent introduction of the exotic pathogen. Our main objective was to develop a diagnostic protocol that could detect the presence of $P$. harknessii within infected host tissue.

The primers ITS1-F and ITS4-B have been utilised to amplify rust DNA in previous studies (Vogler \& Bruns 1998) and the ITS provides a genomic region that is variable 
enough to differentiate between species but is conserved within species (Zambino \& Szabo 1993). The PCR primer Phar1, in conjunction with ITS4-B, was shown to differentiate $P$. harknessii from $C$. comandrae and C. coleosporioides. Unfortunately, DNA from other closely related Cronartium species was unavailable for empirical testing of the novel primer pairs. However, according to sequences lodged in GenBank the protocol will putatively differentiate $P$. harknessii from C. appalachianum, C. comptoniae, $C$. flaccidum, $C$. occidentale, $C$. ribicola and $P$. bethelii because alignment with sequences from the GenBank database indicated that these species are identical to $C$. comandrae and $C$. coleosporioides at the Phar 1 recognition site. Cronartium quercuum $\mathrm{f}$. $\mathrm{sp}$. banksianae is the nearest sibling species to P. harknessii and is hypothesised to share with it a most-recent common ancestor (Vogler \& Bruns 1998). As the primer recognition site varies by only two base pairs between $P$. harknessii and $C$. quercuum, it is not surprising that $C$. quercuum f.sp fusiforme DNA was also amplified by Phar1. The method developed in this study was able to detect the presence of as little as $50 \mathrm{pg} P$. harknessii DNA amongst $10 \mathrm{ng}$ of host DNA. It is concluded that the PCR primers Phar1 and ITS4-B can be utilised to identify $P$. harknessii and $C$. quercuum f.sp. fusiforme within suspicious galls. Currently, this diagnostic test is being refined to allow $P$. harknessii and $C$. quercuum f.sp. fusiforme to be distinguished at the DNA level.

\section{ACKNOWLEDGEMENTS}

Cronartium quercuum f.sp. fusiforme DNA was generously supplied by Dr. Tom Kubisiak, DNA from Pinus radiata was provided by Ms. Lisa McMillan, Dr. Simon Shamoun provided laboratory space for the DNA extraction, and Dr. Paul Zambino provided an aeciospore DNA extraction protocol.

\section{REFERENCES}

Allen, E.A.; Blenis, P.V.; Hiratsuka, Y. 1988: Axenic culture of Endocronartium harknessii. Mycologia 80: 120-123.

Gardes, M.; Bruns, T.D. 1993: ITS primers with enhanced specificity for basidiomycetes - application to the identification of mycorrhizae and rusts. Mol. Ecol. 2: 113-118.

Hiratsuka, Y. 1969: Endocronartium, a new genus for autoecious pine stem rusts. Can. J. Bot. 47: 1493-1495.

Hosking, G.; Carson, M.; Dick, M. 1999: Biosecurity strategies for the pitch canker threat to New Zealand's plantation forests. In: Devey, M.E.; Matheson, A.C.; Gordon, T.R. ed. Current and potential impacts of pitch canker in radiata pine. CSIRO Australia, Forestry and Forest Products, Technical Report No. 112. Pp. 6-11.

Lundquist, J.E.; Walla, J.A.; Tuskan, G.A. 1994: Characteristics of Peridermium harknessii in axenic culture. Can. J. For. Res. 24: 1345-1353.

Old, K.M. 1981: Western gall rust, a serious disease of Pinus radiata in California. Aust. For. 44: 178-184.

Old, K.M.; Libby, W.J.; Russell, H.H.; Eldridge, K.G. 1986: Genetic variability in susceptibility of Pinus radiata to western gall rust. Silvae Genetica 35: 145-149.

Parmeter, J.R. JR; Newhook, F.J. 1967: New Zealand Pinus radiata is susceptible to western gall rust disease. N.Z. J. For. 12: 200-201.

Peterson, R.S. 1960: Development of western gall rust in lodgepole pine. Phytopath. 50: $876-881$.

van der Kamp, B.J. 1989: The relative susceptibility of scots and lodgepole pine to western gall rust. Eur. J. For. Path. 19: 274-280.

Vogler, D.R.; Bruns, T.D. 1998: Phylogenetic relationships among the pine stem rust fungi (Cronartium and Peridermium spp.). Mycologia 90: 244-257.

Zambino, P.J.; Szabo, L.J. 1993: Phylogenetic relationships of selected cereal and grass rusts based on rDNA sequence analysis. Mycologia 85: 401-414.

Zambino, P.J. 2002: Dry grinding at near-ambient temperatures for extracting DNA from rust and other fungal spores. BioTechniques 33: 48-51. 